\title{
Detection of viable and viable nonculturable Vibrio cholerae 01 through cultures and immunofluorescence in the Tucumán rivers, Argentina
}

\author{
Detecção de Vibrio cholerae 01 viável e viável não cultivável, através de técnicas \\ de cultivo e imunofluorescência nos rios de Tucumán, Argentina
}

\author{
Olga Aulet ${ }^{1}$, Clara Silva ${ }^{1}$, Sol González Fraga ${ }^{2}$, Mariana Pichel ${ }^{2}$, Rosa Cangemi ${ }^{1}$, Cristina Gaudioso ${ }^{1}$, \\ Norma Porcel $^{1}$, Maria Angela Jure ${ }^{1}$, Marta Cecilia de Castillo ${ }^{1}$ and Noma Binsztein ${ }^{2}$
}

\begin{abstract}
Vibrio cholerae has been sporadically isolated from rivers in Tucumán, Argentina, since the outbreak in 1991. The aim of this study was to determine the environmental reservoir of the bacterium in these rivers, assessing the presence of Vibrio cholerae non-01 and 01 (the latter both in its viable culturable and non culturable state) and its relationship to environmental physicochemical variables. 18 water samplings were collected in the Sali River (in Canal Norte and Banda) and the Lules River between 2003 and 2005. Physical-chemical measurements ( $p H$, water temperature, electrical conductivity and dissolved oxygen) were examined. Vibrio cholerae was investigated with conventional culture methods and with Direct Immunofluorescence (DFA-VNC) in order to detect viable non culturable organisms. All isolated microorganisms corresponded to Vibrio cholerae non-01 and non-0139 (Lules 26\%, Canal Norte 33\% and Banda 41\%). The majority was found during spring and summer and correlated with temperature and $p H$. Non culturable Vibrio cholerae 01 was detected year round in 38 of the 54 water samples analyzed. Application of the Pearson correlation coefficient revealed that there was no relationship between positive immunofluorescence results and environmental physicochemical parameters. Genes coding for somatic antigen 01 were confirmed in all DFA-VNC-positive samples, whereas the virulence-associated $\mathrm{ctx} A$ and $\mathrm{tcp} A$ genes were confirmed in 24 samples.
\end{abstract}

Key-words: Vibrio cholerae 01. Culture and immunofluorescence. Tucumán rivers.

\section{RESUMO}

Vibrio cholerae tem sido isolado esporadicamente nos rios da Província de Tucumán, Argentina, desde outubro de 1991. O objetivo deste estudo foi localizar os reservatórios nestes rios, identificar a presença de Vibrio cholerae 01 (em estado cultivável e não cultivável) e relacionar a presença desta bactéria com as variações físico-químicos da água. Foram coletadas dezoito amostras de água do rio Sali (nas localidades de Canal Norte e Banda) e do rio Lules, entre 2003 e 2005. Estas foram submetidas a análises físico-químicos como determinação de pH, temperatura, condutibilidade elétrica e oxigênio dissolvido. A presença de Vibrio cholerae foi verificada por métodos de cultivo convencional e por imunofluorescência direta (DFA-VNC). Todos os microrganismos isolados foram não 01 e não 0139 (Lules 26\%, Canal Norte $33 \%$ e Banda 41\%). A maioria foi encontrada na primavera e verão, indicando uma relação com a temperatura e pH. Das 54 amostras analisadas por DFA-VNC, 38 Vibrio cholerae não cultivável, foram detectadas em todas as épocas do ano. As amostras positivas foram confirmadas por PCR para o antígeno somático 01 e para os genes de virulência ctxA e tcpA. Coeficiente de correlação de Pearson revelou que não há relação entre os resultados obtidos por imunofluorescência e a variação dos parâmetros físico-químicos.

Palavras-chaves: Vibrio cholerae 01. Culture and immunofluorescence. Tucumán rivers.

Cholera continues to be an important and devastating disease transmitted by water and food, especially in those regions of the world where it is endemic ${ }^{812}$. Before its reemergence in Peru and subsequent spreading throughout Latin America in 1991, the disease had been absent from the Americas for nearly
100 years $^{14}$. There has been much speculation as to the cause of this reemergence and whether there has always been an environmental reservoir for Vibrio cholerae in Latin America. Since 1991, seasonal patterns of cholera outbreaks have been well documented in Central and South America, with the largest

\footnotetext{
1. Departamento de Microbiología Clínica, Facultad Bioquímica, Química, Farmacia y Biotecnología, Universidad Nacional de Tucumán, Tucumán, Argentina. 2. Instituto Nacional de Enfermedades Infecciosas, National Institute of Infectious Diseases "Carlos G. Malbrán”. Bs As, Argentina.

This study was financially supported by PICT-R 2000-00010 awarded by the Agencia Nacional de Promoción Científica y Tecnológica, Secretary of Science and Technology, Ministry of Culture and Education, Argentina.

Address to: Dr $^{\mathrm{a}}$ Marta Cecilia de Castillo. Departamento de Microbiología Clínica/FBQF/UNT. Ayacucho 491, 4000 SM de Tucumán, Argentina.

Tel: 5403814247752 int 1013

e-mail: microbiologiaclinica@fbqf.unt.edu.ar.

Recebido em:13/10/2006

Aceito em: 12/07/20007
} 
numbers of cases occurring during the warm months (January to March) ${ }^{28}{ }^{39}$. In Argentina, there have been seven epidemics since 1992. These cholera outbreaks occurred mainly during the summer months. Vibrio cholerae 01 strains were isolated from water samples collected from rivers during epidemic periods, but also found in marine waters and the La Plata River estuaries ${ }^{2}$.

Standard bacteriological procedures for isolation of Vibrio choleare 01 from environmental samples (including water) between epidemics were generally unsuccessful ${ }^{19}$. Vibrio cholerae requires salt for growth and can revert to a viable but non culturable state (VNC) in response to adverse environmental conditions. These VNC bacteria do not grow on conventional culture media, but remain intact and retain metabolic activity and respiration ${ }^{6} 293042$. However, the method of Kogure et al can be used to demonstrate that these cells retain viability and their pathogenic potential ${ }^{162532}$. Techniques employing microscopy, with either direct or indirect fluorescent antibodystaining, have been developed and provide important data on the occurrence of viable but nonculturable Vibrio cholerae $01^{19}$.

Since the outbreak in Tucumán, a province in the northwest of Argentina, sporadic cases of diarrhea by Vibrio cholerae have been detected in areas close to the Salí and Lules rivers. This study aimed to detect Vibrio cholerae 01 in these environments using conventional culture techniques to isolate the microorganism and direct immunofluorescence to detect the viable nonculturable state and associate its presence to 4 environmental physicochemical variables.

\section{MATERIAL AND METHODS}

Site description and water sampling. Samples were collected at the Salí River (two sites: Canal Norte (CN) and Banda (B)) and at the Lules River (one site). They were taken during 18 campaigns in a three-year period (2003-2005) with 6 campaigns per year. Water temperature, $\mathrm{pH}$ and electrical conductivity were determined in situ with a mercury thermometer, a portable digital $\mathrm{pH}$ meter (TPA-I) and an Altronix conductivity meter (Ct-1), respectively. Dissolved oxygen (D0) was measured at the laboratory according to the methods by Winkler ${ }^{1}$.

Water samples were collected in sterile 5-liter bottles, and then immediately transported to the laboratory and subjected to bacteriological examination not more than $5 \mathrm{~h}$.

Bacteriological assaying. Two liters of water were filtered through $0.22 \mu \mathrm{m}$ membranes, using 12 to 15 membranes per sample. Membranes were subsequently incubated in $100 \mathrm{ml}$ of alkaline peptone water, $\mathrm{pH} 8.6$, for $6-8 \mathrm{~h}$ at $35^{\circ} \mathrm{C}$. Two loopfuls of broth were streaked on Thiosulfate Citrate Bile agar (TCBS agar, Difco) and incubated for 18h at $37^{\circ} \mathrm{C}$. Six to 12 typical colonies (yellow and 1 to $3 \mathrm{~mm}$ diameter) were transferred to nutritive soft agar ( $\mathrm{T}_{1} \mathrm{~N}_{1}, 0.75 \%$ agar) and incubated for $24 \mathrm{~h}$ at $37^{\circ} \mathrm{C}$. All colonies were stored at room temperature for further testing. Isolates were identified biochemically and serotyped (01 and 0139 antisera from the National Institute of Infectious Diseases-INEI. ANLIS. "Dr Carlos G Malbran”, Buenos Aires, Argentina)

Direct immunofluorescence of Vibrio cholerae 01 (DFA-DVC). Two liters of water were membrane-filtered $(0.22 \mu \mathrm{m})$. Afterwards, the membranes were washed with $8 \mathrm{ml}$ of phosphate buffer, and this buffer was fractioned for direct immunofluorescence of Vibrio cholerae 01 (DFA-DVC) analysis. Samples were previously incubated in the dark for 6 to $8 \mathrm{~h}$ at room temperature in the presence of yeast extract and nalidixic acid. Under these conditions, viable but nonculturable bacteria elongate from a coccoid shape to rod-like cells, yet they do not multiply due to the inhibitory effect of nalidixic acid (a DNA gyrase inhibitor). After incubation, samples were fixed with $4 \%$ formaldehyde and processed with cholera DFA kits (New Horizons Diagnostics Corporation) for detection of Vibrio cholerae $01^{7}{ }^{17}$. Stained preparations were observed under an epifluorescence microscope (1000X) at 490 (maximum excitation) and 520nm (maximum emission) with a blue filter. All procedures were carried out in the dark. Readings were carried out within $24 \mathrm{~h}$ after preparation of the samples.

Confirmation of Vibrio cholerae 01 with polymerase chain reaction. Because DFA-DVC is a presumptive technique presence of the microorganism was confirmed using PCR in water to detect genes coding for the somatic antigens 01 and virulence-associated ctxA genes that code for the A subunit of the cholera toxin (CT) and tcpA El Tor, that codes for the toxin co-regulated pilus (TCP) pilin subunit 593344041 . This method was carried out at the Bacteriology Department of the Institute of Infectious Diseases (INEI) ANLIS “Dr. Carlos G. Malbrán”, Buenos Aires, Argentina.

Statistical analysis. The relationship between detection of Vibrio cholerae and the physicochemical variables assayed was assessed with the Pearson Correlation Coefficient ( $\alpha=0.05^{*}$ or $\left.0.01^{* *}\right)$, using the SPSS statistics program (version 10.0 for Windows).

\section{RESULTS}

Physical and chemical parameters of the water. The water temperature oscillated between 15 and $26^{\circ} \mathrm{C}$, pH between 5.5 and 9.0, Do between 0 and $9 \mathrm{mgl}^{-1}$ and the conductivity between 400 and $1.600 \mu \mathrm{S}$ $\mathrm{cm}^{-1} \cdot \mathrm{pH}$ values at the Salí River sampling sites ( $\mathrm{CN}$ and $\mathrm{B}$ ) oscillated during the three years between acid and alkaline, whereas fluctuations at the Lules River sampling site were between 6.59 and 9.06. Regarding dissolved oxygen, anoxia stages were only observed in the Salí River, which also showed highest conductivity (Figures 1a, b, c).

Viable culturable Vibrio cholerae. A total of 613 suspicious colonies (yellow in TCBS) were isolated from the different sites and 385 were biotypified as Vibrio cholerae non01, non-0139. The percentage of isolates from each site was: RS (CN) $33 \%, \operatorname{RS}$ (B) $41 \%$ and RL 26\%.

Figure 2 shows Vibrio cholerae non-01, non-0139 isolates according to their sampling site during the different months and seasons. The microorganism was mainly isolated during the warm months, corresponding to spring and summer, with a percentage of 30 or more.

When analyzing the correlation between isolation of Vibrio cholerae non-01, non-0139 and physicochemical variables it was found that the highest number of isolations in the Lules River in January, March, November and December with a water temperature over $25^{\circ} \mathrm{C}$ and $\mathrm{pH}$ more than 7.7. DO was between 8.8 and $9 \mathrm{mgl}^{-1}$ and conductivity between 426 and $658 \mu \mathrm{sm}^{-1}$. No isolates were found in June and September with a water 

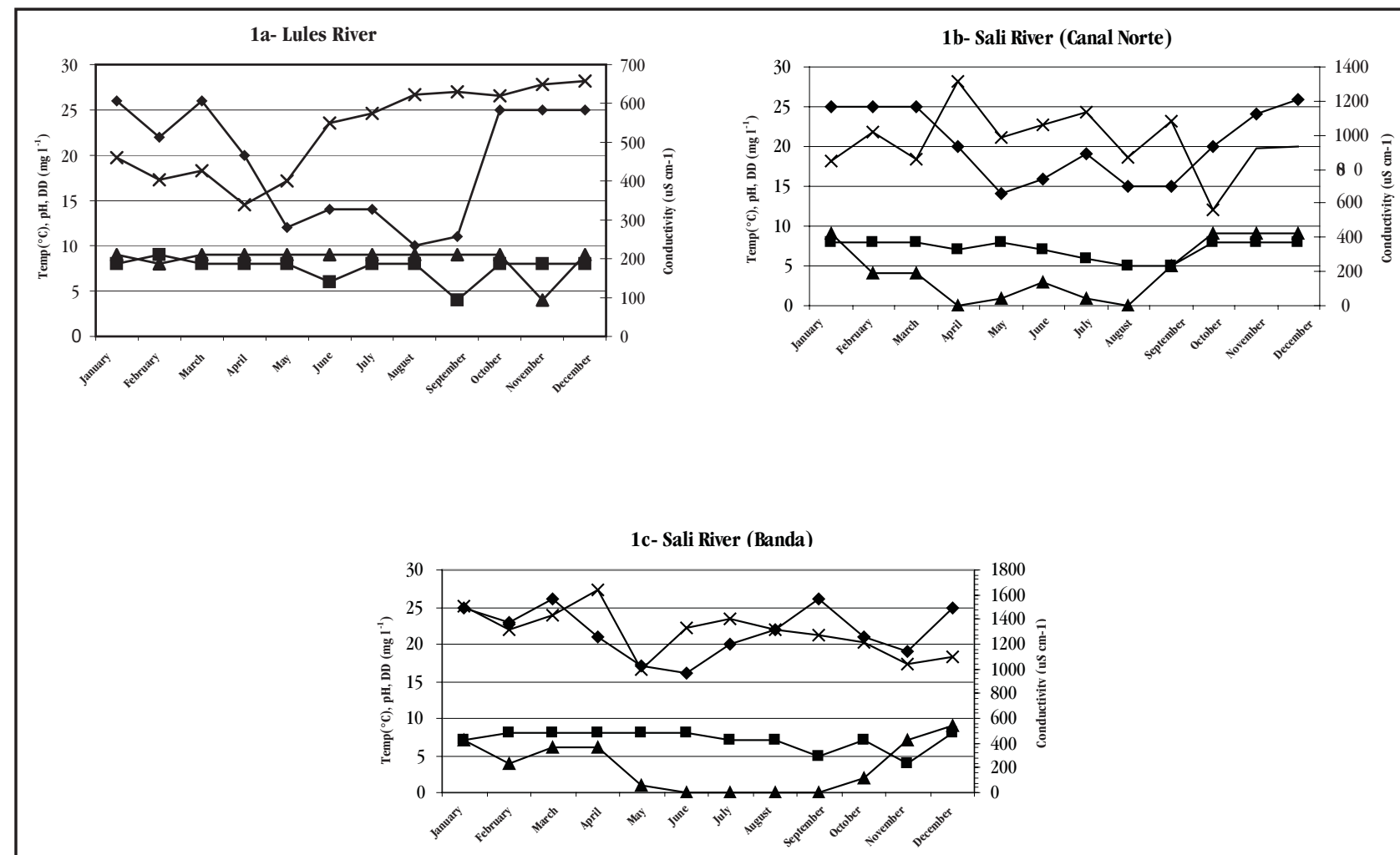

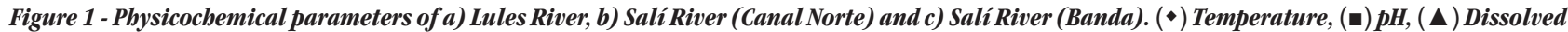
Oxygen (DO) and (x) Conductivity.

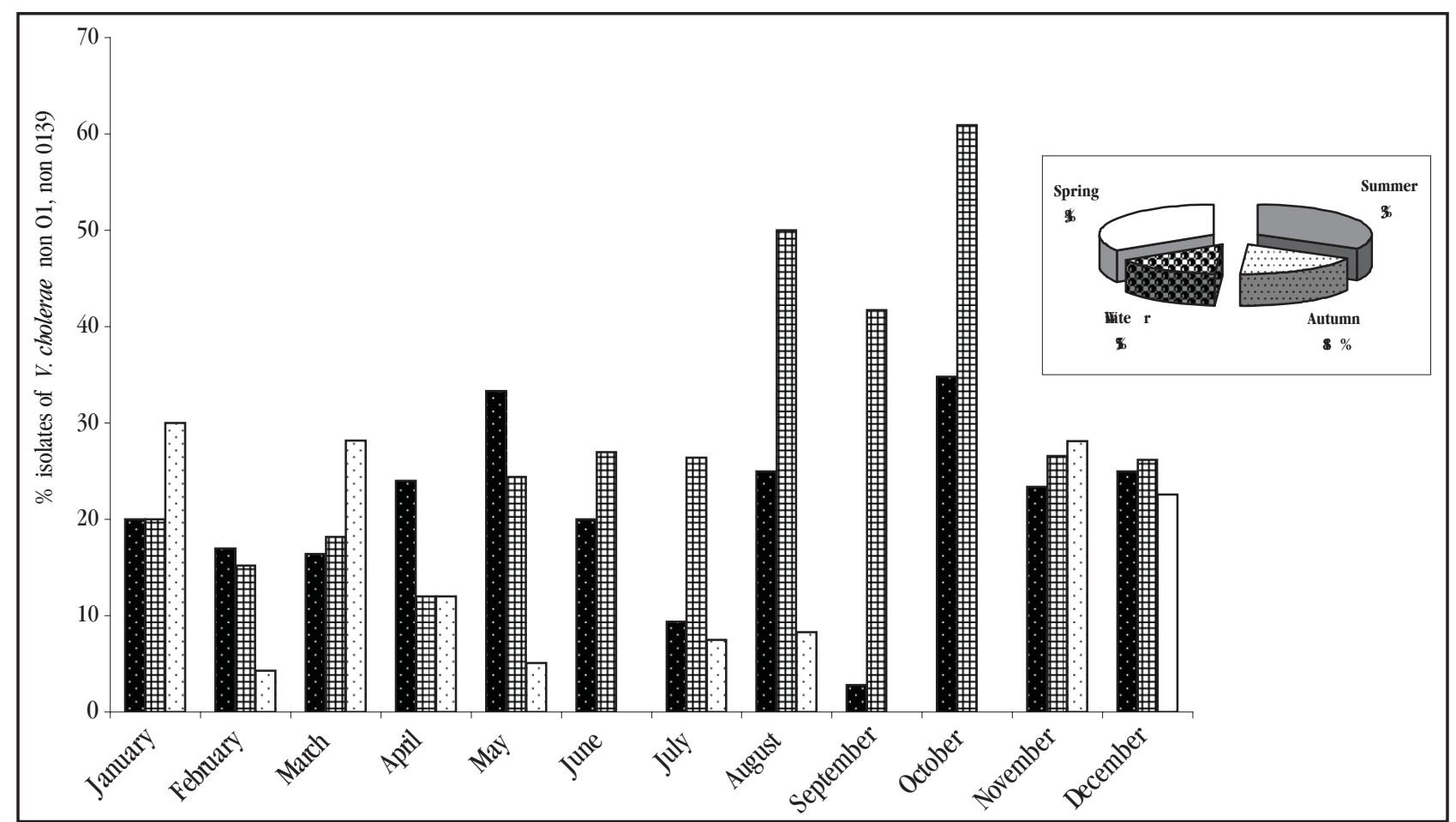

Figure 2 - Percentage of isolation of Vibrio cholerae non-01 at each sample site and during the different months and seasons. Sali River (Canal Norte), Sali River (Banda) and Lules River. 
temperature under $14^{\circ} \mathrm{C}$ and $\mathrm{pH}$ below 6.5. At the Canal Norte sampling site (Salí River) the microorganism was isolated all year round with temperatures and $\mathrm{pH}$ values that oscillated between 14 and $26^{\circ} \mathrm{C}$ and 5 and 8.5 respectively. Furthermore, periods of anoxia were observed and conductivity was generally less than $900 \mu \mathrm{sm}^{-1}$. The highest number of Vibrio cholerae non-01, non-0139 isolates was recovered at the Banda sampling site (Salí River) during the period researched. Water temperature varied from 16 to $26^{\circ} \mathrm{C}$ and the $\mathrm{pH}$ was generally higher than 7 . There were also anoxia periods (June to September) and conductivity was over $1.000 \mu \mathrm{S} \mathrm{cm}^{-1}$.

Figure 3 demonstrates that from the 54 water samples from the different sites analyzed per month 38 were positive for Vibrio cholerae 01 using the direct immunofluorescence (DFA-DVC) technique. Vibrio cholerae 01 (VNC) was detected all year round in rivers in Tucumán with the highest numbers during January, February and June. Water temperature in January and February was over $22^{\circ} \mathrm{C}$ and $\mathrm{pH}$ over 7.5 , figures that are different from those obtained in June with temperatures under $16^{\circ} \mathrm{C}$ and $\mathrm{pH}$ values below 6.5 . Conductivity and DO varied considerably in January, February and June with values between 400 and 1,550 $\mathrm{SS}$ $\mathrm{cm}^{-1}$ and 2.8 and $9 \mathrm{mgl}^{-1}$ respectively. The Pearson correlation coefficient revealed that there was no relationship between positive immunofluorescence results and environmental physicochemical parameters.

Viable but nonculturable Vibrio cholerae. Even though no Vibrio cholerae 01 strains were obtained by conventional culture methods, DFA-DVC revealed the presence of Vibrio cholerae 01 (VNC), which appeared as rod-shaped bacteria after incubation with yeast extract and nalidixic acid (Figure 4).

PCR confirmed presence of genes coding for the somatic antigen 01 in the 38 positive samples for viable nonculturable Vibrio cholerae using immunofluoresence, but the virulence-associated ctx $\mathrm{A}$ and/or tcpA genes were only confirmed in 24 of them.

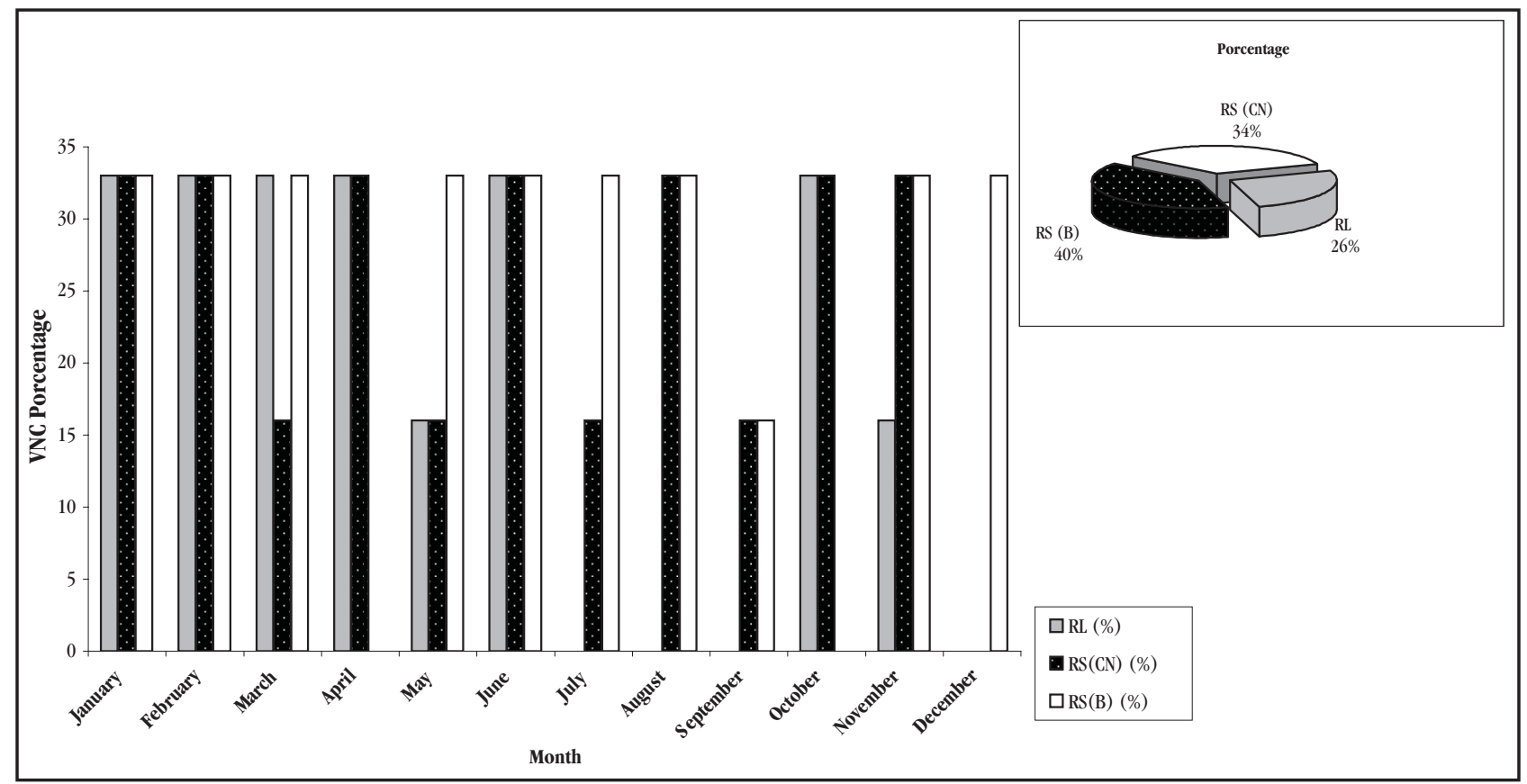

Figure 3 - Detection of Vibrio cholerae 01 VNC using direct immunofluorescence assaying at the different sample sites according to the month. Lules River, Sali River (Canal Norte) and Sali River (Banda).

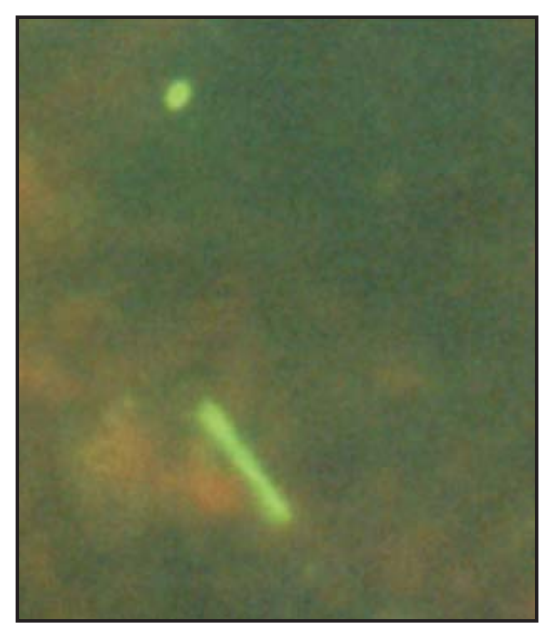

Figure 4 - Detection of viable nonculturable Vibrio cholerae 01 through direct inmunofluorescence. 


\section{DISCUSSION}

In 1977, Colwell et al first hypothesized that coastal waters were an important reservoir of Vibrio cholerae $e^{10}$. Other authors also detected Vibrio cholerae in seawater and other environmental sources around the world, both in cholera-endemic and in cholera-free areas $^{11} 182023243647$.

Borroto, Lee et al, Tamplin and Carrillo isolated Vibrio from water with temperatures between 25 and $12^{\circ} \mathrm{C}$, which is in agreement with our results 32734 .

Singleton et al have concluded that presence of Vibrio 01 in aquatic environments is not limited to estuaries, because its salinity requirements can be met through an adequate nutrient concentration in fresh water environments. It has been reported that this microorganism is able to survive in fresh water for prolonged periods of time $e^{43223537384245}$. Feachem et al and Miller et al have demonstrated that various biological and physicochemical factors influence growth, survival, and distribution of Vibrio cholerae in aquatic environments ${ }^{13} 31$. Isolation of the microorganism with classical culture methods may fail. This depends on the physicochemical properties of the water or the physiological state of Vibrio cholerae 01 itself, either with actively growing cells or cells in a latent or dormant state ${ }^{3137}$. The DFA-DVC technique has shown to be useful for detection of viable but nonculturable Vibrio cholerae 01 in water samples ${ }^{3044}{ }^{46}$. Huq et al isolated Vibrio cholerae 01 from fresh water environments (rivers) using immunofluorescence, but they too were unable to isolate culturable forms with conventional culture methods in Bangladesh. Gonçalves et al found viable nonculturable forms of the Vibrio organism in two river estuaries in Brazil and Binsztein et al detected it for the first time in the La Plata River and close to a marine platform in Argentina ${ }^{2} 15$.

The rivers in Tucumán are affected by effluents of a variety of industries (sugar cane, citric fruit processing and paper among others) that, together with agricultural activities, modify the aquatic environments, thus generating conditions that allow survival of Vibrio cholerae non-01, non-0139 and persistence of the viable nonculturable state of Vibrio cholerae 01 . The fact that Vibrio cholerae 01 was not detected with classical culture methods agrees with results obtained by other researchers ${ }^{2130}$.

Kurazono et al and Sharma et al sustain that the epidemiological impact of environmental Vibrio cholerae strains is not clearly understood, because most of them do not produce the cholera toxin and have also lost significant pathogenic factors ${ }^{2641}$. Similarly, $37 \%$ of the total number of samples that confirmed somatic antigen 01 tested negatively for the virulence-associated $c t x \mathrm{~A}$ and tcpA genes.

Our study has for the first time provided evidence of isolation of Vibrio cholerae non-01, non-0139 and presence of the viable nonculturable state of Vibrio cholerae 01 in rivers in Tucumán all year round. Consequently, it can be inferred that the Lules and Salí rivers constitute a reservoir for the microorganism in our province.

The warm temperatures in addition to a high concentration of organic nutrients from agro-industrial waste, as is the case in the rivers in Tucumán, create in these developing areas with poor sanitary conditions an adequate environment so that Vibrio cholerae can persist. Considering that this water is used for human consumption in rural areas, and that drinking water constitutes an important transmission vehicle of the pathogen, exhaustive monitoring studies would be necessary to determine how these bacteria, present in the rivers, affect public health now and in the future.

\section{REFERENCES}

1. American Public Health Association. Métodos Normatizados para el análisis de aguas potables y residuales. $17^{\circ}$ edición Ed Diaz de Santos, SA. Madrid, 1992.

2. Binsztein N, Costagliola M, Pichel M, Jurquiza V, RamirezF, Akselman R, Vacchino M, Huq A, Cowell R. Viable but nonculturable Vibrio cholerae 01 in the Aquatic Environment of Argentina. Applied and Environmental Microbiology 70:7481-7486, 2004.

3. Borroto RJ. Supervivencia de Vibrio cholerae en agua dulce superficiales y cólera endémico: una hipótesis geoecológica. Revista Panamericana de Salud Pública 4:371-374, 1998.

4. Bourke A, Cossins Y, Gray B. Investigation of cholera acquired from the riverine environment in Queensland. Medical Journal 144:229-234, 1986.

5. Chakraborty S, Mukhopadhyay AK, Bhadra RK, Ghosh AN, Mitra R, Shimada T, Yamasaki S, Faruque SM, Takeda Y, Cowell RR, Nair GB. Virulence genes in environmental strains of Vibrio cholerae. Applied Environmental Microbiology 66:4022-4028, 2000.

6. Choopun N, Louis V, Huq A, Colwell RR. Simple Procedure for Rapid Identification of Vibrio cholerae from the Aquatic Environment. Applied and Environmental Microbiology 68: 995-998, 2002.

7. Chowdhury MAR, Xu B, Montilla R, Hasan JAK, Huq A, Colwell RR. A simplified immunofluorescence technique for detection of viable cell of Vibrio cholerae 01 and 0139. Journal of Microbiology Methods 24:165-170, 1995.

8. Colwell RR. Global climate and Infectious Disease: the cholera paradigm. Science 274: 2025-2031, 1996.

9. Colwell RR, Brayton PR, Grimes DJ, Roszak DR, Huq SA, Palmer LM. Viable, but non-culturable, Vibrio cholerae and related pathogens in the environment: implications for release of genetically engineered microorganisms. Biotechnology 3:817-820, 1985.

10. Colwell RR, Kaper J, Joseph SW. Vibrio cholerae and Vibrio parabaemolyticus and other vibrios: occurrence and distribution in Chesapeake Bay. Science 198:394-396, 1977.

11. Colwell RR, Seidler RJ, Kaper J, Joseph SW, Garges S, Lockman H, Maneval D, Bradford H, Roberts N, Remmers E, Huq I, Huq A. Occurrence of Vibrio cholerae serotype 01 in Maryland and Louisiana estuaries. Applied Environmental Microbiology 41:555-558, 1981.

12. Farruque SM, Albert MJ, Makanos JJ. Epidemiology, genetics and ecology of toxigenic Vibrio cholerae. Microbiology and Molecular Biology Reviews 62:1301-1314, 1998.

13. Feachem R, Miller C, Drasar B. Environmental aspects of cholera epidemiology. II. Occurrence and survival of $V$. cholerae in the environment. Tropical. Disease Bulletin 78:865-880, 1981.

14. Franco AA, Fix AD, Prada A, Paredes E, Palomino JC, Wright AC, Johnson JA, McCarter R, Guerra H, Morris JG. Cholera in Lima, Peru, correlates with prior isolation of Vibrio cholerae from the environment. American Journal of Epidemiology 146:1067-1075, 1997.

15. Gonçalves EGR, Lopes MJ S, Olivera EG, Hofer E. Associacao de Vibrio cholerae com o zooplancton de aguas estuarios da Baía de São Luis- MA, Brasil. Revista da Sociedade Brasileira de Medicina Tropical 37:318-323, 2004.

16. Grimes DJ, Atwell RW, Brayton PR, Palmer LM, Rollins DM, Roszak DB, Singleton FL, Tamplin ML, Colwell RR. The fate of enteric pathogenic bacteria in estuarine and marine environments. Microbiological Science 3:324-329, 1986.

17. Hasan J, Bernstein D, Huq A, Loomis L, Tamplin M, Cowell R. Cholera DFA: an improvd direct fluorescent monoclonal antibody staining kit for rapid detection 
and enumeration of Vibrio cholerae 01. FEMS Microbiology Letters 120: 143-148, 1994

18. Huq A, Colwell RR. Vibrios in the marine and estuarine environment: tracking of Vibrio cholerae. Journal of Ecosystems and Health 2:198-214, 1996.

19. Huq A, Cowell RR, Rahman R, Ali A, Chowdhury MA, Parveen S, Sack DA, Russek-Cohen E. Detection of Vibrio cholerae 01 in the aquatic environment by fluorescent-monoclonal antibody and culture methods. Applied Environmental Microbiology 57:2370-2373, 1990.

20. Huq A, Sack R, Colwell RR. Cholera and global ecosystems. In: Aron J, Patz J (eds) Ecosystem change and public health: a global perspective, Johns Hopkins University Press, Baltimore, Maryland, p. 327-347, 2001.

21. Huq A, Small EB, West PA, Huq MI, Rahman R, Colwell RR. Ecological relationship between Vibrio cholerae and planktonic crustacean copepods. Applied and Environmental Microbiology 45:275-283, 1983.

22. Islam MS, Drasar BS, Sack RB. The aquatic flora and fauna as reservoir of Vibrio cholerae: a review. Journal of Diarrhea Disease Research 12:87-96, 1994.

23. Jesudason MV, Balaji V, Mukudan U, Thomas CJ. Ecological study of Vibrio cholerae in Vellore. Epidemiology Infection 124:201-206, 2000.

24. Kaysner CA, Abeyta Jr C, Wekell MM, DePaola Jr A, Stott RF, Leitch JM. Incidence of Vibrio cholerae from estuaries of the United States West Coast. Applied and Environmental Microbiology 53:1344-1348, 1987.

25. Kogure K, Simidu U, Taga N. A tentative direct microscopic method for counting living marine bacteria. Canadian Journal of Microbiology 25:415-420, 1979.

26. Kurazono H, Pal A, Bag PK, Nair GB, Karasawa T, Mihara T, Takeda Y. Distribution of genes encoding cholera toxin, zonula occludens toxin, accessory cholera toxin, and El Tor hemolysin of diverse origins. Microbiology Pathogenic 18:231-235, 1995

27. Lee J, Bashford D, Donovan T, Furniss A, West P. The incidence of Vibrio cholerae in water, animals, and birds in Kent, England. Journal of Applied Bacteriology 52:281-291, 1982.

28. Lipp E, Gil AI, Espeland EM, Choopun N, Louis VR, Russek-Cohen E, Huq A, Colwell RR. Direct Detection of Vibrio cholerae and ctxA in Peruvian Coastal Water and Plankton by PCR. Applied and Environmental Microbiology 69:36763680, 2003.

29. Louis VR, Russek-Cohen E, Choopun N, Rivera IN, Gangle B, Jiang SC, Rubin A, HuqJA, Colwell RR. Predictability of Vibrio cholerae in Chesapeake Bay. Applied and Environmental Microbiology 69: 2773-2785, 2003

30. Martins MT, Sanchez PS, Sato MIZ, Brayton PR, Colwell RR. Detection of Vibrio cholerae 01 in the aquatic environment in Brazil employing direct immunofluorescence microscopy. World Journal of Microbiology and Biotechnology 9:390-392, 1993

31. Miller CJ, Drasar B, Feachem RG. Response of toxogenic Vibrio cholerae 01 to physiological stresses in aquatic environments. Journal of Hygiene 93:475-495, 1984

32. Nilsson L, Oliver JD, Kjelleberg S. Resuscitation of Vibrio cholerae from the viable but nonculturable state. Journal of Bacteriology 173:5054-5059, 1991.
33. Rivera I, Chun J, Huq A, Sack R, Colwell RR. Genotypes associated with virulence in environmental isolates of Vibrio cholerae. Applied Environmental Microbiology 67: 2421-2429, 2001.

34. Rivera I, Lipp E, Gil A, Choopun N, Huq A, Colwell RR. Method for extraction and application of Multiplex PCR to detect Toxigenic V. cholerae 01 and 0139 from aquatic ecosystems. Environ Microbiol 5: 599-606, 2003.

35. Rogers R, Cuffe R, Cossins Y, Murphy D, Bourke A. The Queensland cholera incident of 1977. II, The epidemiological investigation. Bulletin World Health Organ 58:665-669, 1980.

36. Rollins DM, Colwell RR. Viable but nonculturable stage of Camylobacter jejuni and its role in survival in the natural aquatic environment. Applied Environmental Microbiology 52:531-538, 1986.

37. Roszak DB, Colwell RR. Survival strategies of bacteria in the natural environments. American Journal of Public Health 51:365-379, 1987.

38. Roszak DB, Grimes DJ, Colwell RR. Viable but nonrecoverable stage of Salmonella enteritidis in aquatic systems. Canadian Journal of Microbiology 30:334-338, 1984

39. Seas C, Miranda J, Gil AI, Leon-Baru R, PatzJA, Huq A, Colwell RR, Sack RB. New insights on the emergence of cholera in Latin America during 1991: the Peruvian experience. The American Journal of Tropical Medicine and Hygiene 62:513-517, 2000.

40. Shangkuan Y, Show Y and Wang T. Multiplex polymerase chain reaction to detect toxigenic V. cholerae and to biotype V. cholerae 01. Journal Applied Bacteriology 79: 264-273,1995.

41. Sharma C, Thungapathra M, Ghosh A, Mukhopadhvay AK, Basu A, Mitra R, Basu I, Bhattacharya SK, Takeda T, Yamasaki S, Takeda Y, Fair GB. Molecular analysis of non -01, non-0139 Vibrio cholerae associated with an unusual upsurge in the incidence of cholera-like disease in Calcutta, India. Journal of Clinical Microbiology 36:756-763, 1998.

42. Singleton F, Attwel R, Jangi M, Colwel R. Effects of temperature and salinity on Vibrio cholerae growth. Applied and Environmental Microbiology 44:10047-1058, 1982.

43. Tamplin M, Carrillo C, Environmental spread of Vibrio cholerae in Peru. Lancet 338:1216-1217, 1991

44. Tamplin ML, Gauzens AL, Huq A, Sack DA, Cowell RR. Attachment of Vibrio cholerae serogroup 01 to zooplankton and phytoplankton of Bangladesh waters. Applied and Environmental Microbiology 56:1977-1980, 1990.

45. Venkateswaran KT, Navarro IM, Nakano H, Hashimoto H, Sibling RL. Ecology of Vibrio cholerae non 01 and Salmonella spp. and the role of zooplankton in their seasonal distribution in Fukuyama coastal water, Japan. Applied Environmental Microbiology 35:1591-1598, 1989.

46. Xu HS, Roberts NC, Adams LB, West PA, Siebeling RJ, Huq A, Huq MI, Rahman $\mathrm{R}$, Cowell RR. An indirect fluorescent antibody staining procedure for detection of Vibrio cholerae serovar 01 in aquatic environmental samples. Journal of Microbiological Methods 2:221-231, 1984.

47. Xu HS, Roberts NC, Singleton FL, Attwell RW, Grimes DJ, Colwell RR. Survival and viability of nonculturable Escherichia coli and Vibrio cholerae in the estuarine and marine environment. Microbial Ecology 8:313-323, 1982. 